\title{
PENGARUH UKURAN PERUSAHAAN, NET PROFIT MARGIN DAN DEBT TO EQUITY RATIO TERHADAP AUDIT DELAY
}

\author{
Susi Susilawati ${ }^{1}$, Aditya Safary ${ }^{2}$ \\ ${ }^{11}$ STIE Muhammadiyah Jakarta, sslawati10@gmail.com \\ ${ }^{2}$ Universitas Islam Attahiriyah, aditya.safari86@gmail.com
}

\begin{abstract}
ABSTRAK
Tujuan penelitian ini adalah untuk menguji pengaruh ukuran perusahaan, net profit margin dan debt to equity ratio terhadap audit delay. Populasi dalam penelitian ini adalah perusahaan sub sektor perkebunan yang terdaftar di Bursa Efek Indonesia Periode 2014 hingga 2018. Teknik pengambilan sampel menggunakan metode purposive sampling dimana dari 18 perusahaan terpilih sesuai kriteria sebanyak 11 perusahaan. Teknik analisis yang digunakan dalam penelitian ini adalah analisis regresi linier berganda. Hasil analisis menunjukkan bahwa ukuran perusahaan dan net profit margin tidak berpengaruh terhadap audit delay sedangkan debt to equity ratio berpengaruh terhadap audit delay. Hal ini berarti, besar kecilnya perusahaan dan tinggi rendahnya tingkat profitabilitas tidak menentukan perusahaan tersebut akan melakukan penundaan atau keterlambatan dalam penyampaian laporan keuangan, begitupun perusahaan yang memiliki utang besar akan cenderung lebih cepat dalam penyampain laporan keuangannya. Kata Kunci: audit delay, ukuran perusahaan, net profit margin, debt to equity ratio
\end{abstract}

\begin{abstract}
The purpose of this research is is to test the influence the size of company, net profit margins and debt to equity ratio about the audit delay. The population in this research is the sub-sector companies listed on the Indonesia Stock Exchange from 2014 to 2018. The sampling technique uses a purposive sampling method in which of the 18 companies selected according to the criteria as mush as 11 companies. The analitycal technique used in this study are multiple linear regression analysis. The result of the analysis showed that the size of the company and net profit margin does not affect the audit delay while the debt to equity ratio affects the audit delay. the size of the company and the high or low level of profitability does not determine the company will make a delay or delay in the submission of financial statements, as well as companies that have large debts will tend to be faster in delivering financial statement

Keywords: audit delay, size of the company, net profit margin, debt to equity ratio
\end{abstract}

Naskah diterima: 21-04-2020, Naskah dipublikasikan: 30-04-2020

\section{PENDAHULUAN}

Laporan keuangan harus disusun sesuai standar yang berlaku agar dapat memenuhi kebutuhan seluruh pihak yang menggunakannya (Megayanti, 2016). Dalam pengungkapannya laporan keuangan harus disampaikan dengan jelas, lengkap dan dapat menggambarkan urutan waktu atas segala kejadian ekonomi yang mempunyai pengaruh terhadap hasil operasi usaha sebuah perusahaan.

Di Indonesia, ketepatan waktu penyajian laporan keuangan perusahaan kepada publik diatur dalam UU No.8 Tahun 1995 tentang "Pasar Modal” (Kowanda.,d.k.k, 2016), pada tanggal 5 Juli 2011 Bapepam-LK menerbitkan peraturan No. X.K.2 Lampiran Keputusan Ketua Bapepam LK No.Kep-346/BL/2011 mengenai "Kewajiban Penyampaian Laporan Keuangan Berkala”(Annisa, 2018). Keterlambatan dalam penyampaian laporan keuangan akan 
memberikan sinyal buruk bagi para investor untuk berinvestasi karena dianggap perusahaan tersebut dalam kondisi yang kurang baik. Menurut Ningsih dan Widhiyani (2015), Perusahaan dengan kondisi yang baik biasanya menerbitkan laporan keuangan lebih cepat dibandingkan dengan waktu yang ditentukan oleh Bapepam-LK.

Tuntutan akan kepatuhan dalam menyampaikan laporan keuangan auditan perusahaan publik yang ada di Indonesia, menyebabkan permintaan atas jasa audit meningkat. Dari proses audit tersebut perusahaan berharap opini yang baik dengan waktu yang singkat, tetapi auditor harus tetap mengikuti standar professional akuntan publik. Laporan keuangan yang disampaikan dengan tepat waktu akan memiliki kredibilitas yang tinggi dibandingkan dengan yang tidak tepat waktu (Dewayani et.al., 2017).

Audit delay dapat dipengaruhi beberapa faktor seperti ukuran perusahaan, net profit margin dan debt to equity ratio. Ukuran perusahaan dikategorikan besar kecilnya sebuah perusahaan dapat dilihat dari total asset yang dimiliki perusahaan.

Fenomena audit delay bukanlah hal baru di Indonesia. Berdasarkan berbagai sumber, di bawah ini terdapat jumlah perusahaan yang masih terlambat dalam mempublikasikan laporan keuangannya terhitung untuk laporan keuangan per 31 Desember 2012 hingga 31 Desember 2018

Tabel 1.

Jumlah Emiten Yang Terlambat Menyampaikan Laporan Keuangan

\begin{tabular}{c|c}
\hline $\begin{array}{c}\text { LAPORAN KEUANGAN PER 31 } \\
\text { DESEMBER }\end{array}$ & JUMLAH PERUSAHAAN \\
\hline 2012 & 52 \\
2013 & 49 \\
2014 & 52 \\
2015 & 18 \\
2016 & 17 \\
2017 & 10 \\
2018 & 10
\end{tabular}

Sumber : idx.co.id

Berdasarkan data di atas, seperti pada tahun 2018 tercatat ada 10 perusahaan yang menunjukkan adanya audit delay. PT Bursa Efek Indonesia (BEI) mengganjar denda dan menghentikan sementara (suspensi) perdagangan saham 10 perusahaan tercatat (emiten), dua diantaranya dihentikan sementara (suspensi) perdagangan sahamnya yaitu PT. Apexindo Pratama Duta (APEX), Tbk dan PT. Sunson Textile Manufacture Tbk (SSTM) serta BEI juga memperpanjang suspensi perdagangan efek kepada delapan perusahaan karena terlambat menyampaikan laporan keuangan (lapkeu) audit periode 31 Desember 2018. Bursa telah memberikan peringatan tertulis III dan denda senilai Rp150 juta kepada perusahaan tercatat yang terlambat menyampaikan laporan keuangan auditan antara lain PT. Apexindo Pratama Duta (APEX), PT. Bara Jaya Internasional Tbk (ATPK), PT. Borneo Lumbung Energi \& Metal Tbk (BORN), PT. Capitaline Investment Tbk (MTFN), PT. Truba Alam Manunggal Engineering Tbk (TRUB), PT. Cakra Mineral Tbk (CKRA), PT. Evergreen Invesco Tbk (GREN), PT. Merck Sharp Dohme Pharma Tbk (SCPI), Tbk dan PT. Sunson Textile Manufacture Tbk (SSTM), PT. Zebra Nusantara Tbk (ZBRA).

Beberapa penelitian terdahulu mencoba melakukan penelitian mengenai pengaruh ukuran perusahaan terhadap audit delay dan didapatkan hasil yang berbeda-beda. Menurut penelitian Wahyuningsih (2016), Prabasari dan Merkusiwati (2017), Puspitasari dan Latrini (2014) hasil penelitiannya bahwa Ukuran Perusahaan mempunyai pengaruh signifikan terhadap audit delay, Karina Harjanto (2017), Khoufi (2018), Sari et.al., (2014), Kowanda et.al., (2016), 
Saemargani dan Mustikawati (2015) dan Arisudhana (2012) menunjukkan ukuran perusahaan tidak berpengaruh signifikan terhadap Audit Delay.

Selain ukuran perusahaan, variable net profit margin dan debt to equity ratio juga dapat digunakan dalam menganalisa audit delay. Hasil penelitian Ningsih \& Widhiyani (2015) menunjukkan bahwa Net Profit Margin (NPM) berpengaruh signifikan terhadap audit delay, sedangkan penelitian Sinurat dan Sitanggang (2015), menunjukkan bahwa Net Profit Margin (NPM) tidak berpengaruh signifikan terhadap Audit Delay sedangkan Kowanda et al. (2016) hasil penelitiannya adalah bahwa Net Profit Margin (NPM) tidak berpengaruh signifikan terhadap Audit Delay . Putra (2016), Sari et al. (2014), menunjukkan hasil penelitiannya bahwa Debt to Equity Ratio berpengaruh signifikan terhadap Audit Delay, sedangkan Eksandy (2017), Khoufi (2018) menunjukkan hasil bahwa Debt to Equity Ratio tidak berpengaruh signifikan terhadap Audit Delay.

Tabel 2.

Research Gap

\begin{tabular}{|c|c|c|}
\hline Variabel & Peneliti & Hasil Penelitian \\
\hline \multirow[t]{2}{*}{$\begin{array}{c}\text { Ukuran } \\
\text { Perusahaan }\end{array}$} & $\begin{array}{ll}\text { - } & \text { Wahyuningsih (2016), } \\
\text { - } & \text { Prabasari dan Merkusiwati (2017), } \\
\text { - } & \text { Puspitasari dan Latrini (2014) }\end{array}$ & $\begin{array}{c}\text { Berpengaruh negatif } \\
\text { signifikan terhadap audit } \\
\text { delay }\end{array}$ \\
\hline & $\begin{array}{ll}\text { - } & \text { Karina Harjanto (2017), } \\
\text { - } & \text { Khoufi (2018), } \\
\text { - } & \text { Sari et al. (2014), Kowanda et al. } \\
\text { (2016), } \\
\text { - } \quad \text { Saemargani dan Mustikawati (2015) } \\
\text { - } \quad \text { Arisudhana (2012) }\end{array}$ & $\begin{array}{c}\text { Tidak berpengaruh } \\
\text { signifikan terhadap Audit } \\
\text { Delay. }\end{array}$ \\
\hline \multirow[t]{2}{*}{$\begin{array}{l}\text { Net Profit } \\
\text { Margin }\end{array}$} & - $\quad$ Ningsih \& Widhiyani (2015) & $\begin{array}{c}\text { Berpengaruh negatif } \\
\text { signifikan terhadap Audit } \\
\text { Delay }\end{array}$ \\
\hline & $\begin{array}{ll}- & \text { Sinurat dan Sitanggang (2015), } \\
\text { - } & \text { Kowanda et al. (2016) }\end{array}$ & $\begin{array}{c}\text { Tidak berpengaruh } \\
\text { signifikan terhadap Audit } \\
\text { Delay }\end{array}$ \\
\hline \multirow[t]{3}{*}{$\begin{array}{l}\text { Debt to Equity } \\
\text { Ratio }\end{array}$} & $\begin{array}{ll}\text { - } & \text { Putra (2016), } \\
\text { - } & \text { Kowanda et al. (2014) }\end{array}$ & $\begin{array}{c}\text { Berpengaruh positif } \\
\text { signifikan terhadap Audit } \\
\text { Delay }\end{array}$ \\
\hline & $\begin{array}{ll}\text { - } & \text { Sari et al. (2014) }\end{array}$ & $\begin{array}{c}\text { Berpengaruh negatif } \\
\text { signifikan terhadap Audit } \\
\text { Delay }\end{array}$ \\
\hline & $\begin{array}{ll}\text { - } & \text { Eksandy (2017), } \\
\text { - } & \text { Khoufi (2018) }\end{array}$ & $\begin{array}{c}\text { Tidak berpengaruh } \\
\text { signifikan terhadap Audit } \\
\text { Delay. }\end{array}$ \\
\hline
\end{tabular}

Berdasarkan latar belakang tersebut, hasil dari penelitian terdahulu menghasilkan kesimpulan yang berbeda-beda, serta adanya keterlambatan penyampaian laporan keuangan (audit) setiap tahunnya dengan jumlah yang berbeda-beda. Meskipun melihat dari sisi jumlah terus mengalami penurunan tetapi peneliti memandang perlu dilakukan penelitian kembali tentang pengaruh ukuran perusahaan, net profit margin dan debt to equity ratio terhadap audit delay. 


\section{KAJIAN LITERATUR}

\section{Teori Kepatuhan (Compliance Theory)}

Menurut penelitian-penelitian sebelumnya kepatuhan berasal dari kata patuh yang berarti suka menurut perintah, taat kepada perintah atau aturan dan berdisiplin (Annisa, 2018). Menurut Prabasari dan Merkusiwati (2017), teori kepatuhan yaitu suatu bentuk kedisiplinan dalam melaksanakan perintah. Annisa (2018) menyebutkan bahwa patuh dalam kamus ilmiah populer diartikan, sebagai tindakan taat, turut perintah, setia dan loyal akibat motif-motif internal individu. Teori kepatuhan telah diteliti dalam ilmu-ilmu sosial khususnya di bidang psikologi dan sosiologi yang lebih menekankan pada pentingnya proses sosialisasi dalam mempengaruhi perilaku kepatuhan seorang individu

Tuntutan akan kepatuhan terhadap ketepatan waktu dalam penyampaian laporan keuangan tahunan perusahaan publik di Indonesia telah diatur dalam Undang-Undang Nomor 8 Tahun 1995 tentang "Peraturan Pasar Modal” (Annisa, 2018). Dalam hal teori kepatuhan, Bapepam-LK dalam hal ini memberikan aturan melalui peraturan Bapepam (Aditya dan Anisykurlillah, 2014) lampiran Keputusan Ketua BAPEPAM dan LK Nomor KEP346/BL/2011 tentang Kewajiban Penyampaian Laporan Keuangan Berkala, BAPEPAM dan LK mewajibkan setiap perusahaan publik yang terdaftar di Pasar Modal wajib menyampaikan laporan tahunan yang disertai dengan laporan keuangan auditor independen kepada BAPEPAM dan LK selambat-lambatnya pada akhir bulan ketiga (90 hari) setelah tanggal laporan keuangan tahunan (Annisa, 2018).

\section{Audit Delay}

Audit delay mengimplikasikan bahwa laporan keuangan disajikan pada suatu interval waktu, maksudnya untuk menjelaskan perubahan di dalam perusahaan yang mungkin mempengaruhi pengguna pada waktu membuat prediksi dan keputusan. Apabila informasi tersebut tidak disampaikan tepat waktu akan menyebabkan informasi kehilangan nilainya di dalam mempengaruhi kualitas keputusan. Senjang waktu audit dihitung dari selisih tanggal laporan keuangan tahunan perusahaan sampai dengan laporan audit yang dikeluarkan oleh KAP (Puspitasari dan Latrini, 2014).

Menurut Gilling (1977), ketepatan waktu pelaporan keuangan perusahaan akan sangat besar ditentukan oleh manajemen karena memberlakukan batasan waktu pada auditor. Namun dalam tidak adanya kendala seperti itu, keterlambatan pelaporan akan sangat ditentukan oleh kecepatan dan efisiensi proses audit dan cara auditor menjadwalkannya kerja. Ini juga menunjukkan bahwa penelitian empiris memperluas ruang lingkup analisis dan mengintegrasikan banyak pertimbangan, hal ini dapat memberi gambaran yang lebih komprehensif tentang efek dari berbagai faktor pada ketepatan waktu pelaporan keuangan dan audit delay.

\section{Ukuran Perusahaan}

Menurut Ningsih \& Widhiyani (2015), ukuran perusahaan merupakan volume besar kecilnya perusahaan yang dilihat dari jumlah asset perusahaan. Didalam Kamus Besar Bahasa Indonesia, ukuran diartikan sebagai berikut (Munawaroh \& Ramdany, 2019):

1. Alat untuk mengukur (seperti meter, jangka dan sebagainya)

2. Sesuatu yang dipakai untuk menentukan,

3. Pendapatan mengukur, dan

4. Panjangnya (lebarnya, luasnya, besarnya) sesuatu.

Ukuran perusahaan dapat diukur dari total aktiva, total penjualan, jumlah tenaga kerja dan sebagainya. berbagai penelitian yang dilakukan peneliti terdahulu menyatakan bahwa perusahaan besar diduga akan menyelesaikan proses auditnya lebih cepat dibandingkan perusahaan kecil. Hal ini disebabkan oleh beberapa faktor yaitu manajemen perusahaan yang berskala besar cenderung diberikan insentif untuk mengurangi audit delay dikarenakan perusahaan-perusahaan tersebut dimonitor secara ketat oleh investor, pengawas permodalan dari 
pemerintah. Pihak-pihak ini sangat berkepentingan terhadap informasi yang termuat dalam laporan keuangan (Kowanda et al., 2016). Ukuran Perusahaan yang diproksikan dengan total asset dengan menggunakan pengukuran logaritma natural untuk mengetahui besar atau kecilnya sebuah perusahaan.

\section{Net Profit Margin (NPM)}

Menurut Kowanda et al. (2016), Net Profit Margin adalah kemampuan perusahaan menghasilkan laba bersih berdasarkan perbandingan total jumlah laba bersih dengan total jumlah pendapatan perusahaan. Menurut Harahap ( 2011 : 304). Net Profit Margin adalah rasio untuk menunjukkan berapa pesentase pendapatan bersih diperoleh disetiap penjualan Semakin tinggi nilai net profit margin maka akan semakin baik operasi suatu perusahaan, dimana rasio ini dapat diukur dengan rumus (Harahap, 2011) :

Net Profit Margin $=\underline{\text { Earning After Interesst and Tax }}$

\section{Sales}

\section{Debt to Equity Ratio (DER)}

Debt To Equity Ratio menggambarkan proporsi antara kewajiban yang dimiliki dan seluruh kekayaan yang dimiliki. Rasio ini digunakan untuk mengukur kemampuan perusahaan untuk memenuhi kewajiban jangka pendek maupun kewajiban jangka panjang. Semakin tinggi hasilnya, maka cenderung semakin besar resiko keuangan bagi kreditur maupun pemegang saham. Semakin besarnya hutang jangka panjang suatu perusahaan, maka perusahaan tersebut akan cenderung mendapat tekanan untuk menyediakan laporan keuangan auditannya secepatnya bagi pihak kreditur (Supriyati, 2012). Harahap (2010 : 303) menyatakan bahwa debt to equity ratio menggambarkan sampai sejauh mana modal pemilik dapat menutupi utang-utang kepada pihak luar. Pada rasio ini, Semakin kecil nilai rasionya maka akan semakin baik. Dengan kata lain, rasio ini berfungsi untuk mengetahui setiap rupiah dari modal sendiri yang dijadikan jaminan atas utang. Rasio ini dapat diukur dengan rumus (Harahap (2010) :

Debt to Equity Ratio $=\underline{\text { Total Hutang }}$

Modal

\section{Pengembangan Hipotesis}

Ketepatan waktu penerbitan laporan keuangan auditan merupakan hal yang sangat penting khususnya untuk perusahaan-perusahaan publik yang menggunakan pasar modal sebagai salah satu sumber pendanaan. Namun, auditor memerlukan waktu yang cukup lama untuk mengumpulkan bukti-bukti kompeten yang mendukung opininya (Annisa, 2018) sehingga seringkali terjadi audit delay. Menurut Lestari dan saitri (2017), Manajemen dengan skala besar cenderung diberikan insentif untuk mempercepat penerbitan laporan keuangan auditan dan cenderung tidak mengalami audit delay, hal tersebut disebabkan perusahaan berskala besar dimonitor secara ketat oleh investor, pengawas permodalan dan pemerintah sehingga cenderung menghadapi tekanan eksternal yang lebih tinggi untuk mengumumkan laporan keuangan auditan lebih awal. Hal ini didukung oleh penelitian terdahulu seperti Wahyuningsih (2016), Prabasari dan Merkusiwati (2017), Puspitasari dan Latrini (2014) yang menyatakan bahwa ukuran perusahaan mempunyai pengaruh negatif signifikan terhadap audit delay.

\section{H1 : Ukuran Perusahaan berpengaruh negatif signifikan terhadap Audit Delay}

Perusahaan yang memiliki Net Profit Margin tinggi dapat dikatakan bahwa laporan keuangan perusahaan tersebut mengandung berita baik dan perusahaan yang mengalami berita baik akan cenderung menyerahkan laporan keuangannya tepat waktu. Sebaliknya, jika Net Profit Margin perusahaan rendah atau mengalami kodisi/berita buruk, maka perusahaan cenderung terlambat menyerahkan laporan keuangannya. Sehingga dapat disimpulkan bahwa perusahaan yang 
menghasilkan laba positif /net profit margin tinggi akan cenderung tidak mengalami audit delay. Hal ini sejalan dengan hasil penelitian Ningsih \& Widhiyani (2016) yang menyatakan bahwa net profit margin berpengaruh negatif terhadap audit delay.

\section{H2 : Net Profit Margin berpengaruh negatif signifikan terhadap Audit Delay}

Debt to equity ratio menunjukkan kemampuan modal sendiri dalam membiayai utang yang dimiliki perusahaan. Hutang merupakan salah satu aspek yang menjadi dasar penilaian bagi investor untuk mengukur kondisi keuangan (Putra, 2016). Debt to Equity Ratio yang tinggi menggambarkan bahwa perusahaan sedang mengalami kesulitan perusahaan. Kesulitan perusahaan menunjukkan tingginya risiko perusahaan sehingga membuat perusahaan cenderung menunda penyampaian laporan keuangan kepada BAPEPAM-LK. Tingkat hutang perusahaan yang tinggi akan membuat auditor lebih berhati-hati untuk melakukan auditnya, karena hal ini dapat memicu resiko kerugian dari perusahaan itu, sehingga menyebabkan audit delay semakin lama. Putra (2016), Kowanda et al. (2016) menunjukkan hasil penelitiannya bahwa Debt to Equity Ratio berpengaruh positif dan signifikan terhadap Audit Delay

\section{H3 : Debt to Equity Ratio berpengaruh positif signifikan terhadap Audit Delay}

Berdasarkan uraian tersebut di atas, maka kerangka pemikiran teoritis yang menggambarkan variabel-variabel yang dapat mempengaruhi terhadap audit delay adalah sebagai berikut :

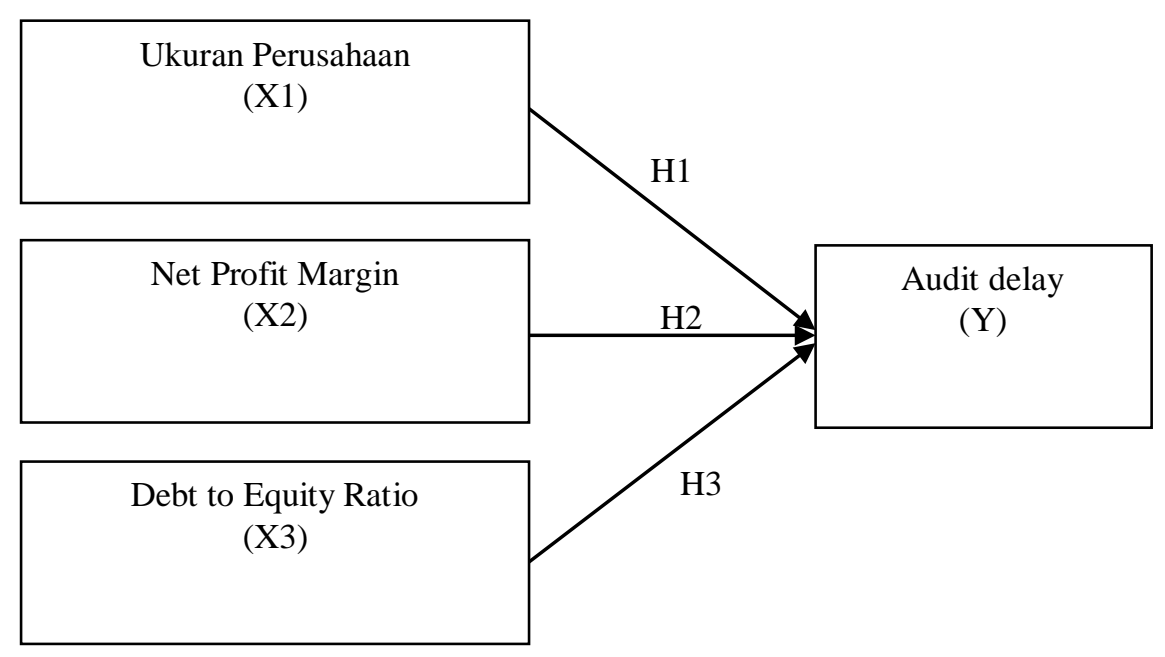

Gambar 1. Kerangka Pikir

\section{METODE PENELITIAN}

Penelitian dilakukan terhadap perusahaan sub sector perkebunan yang terdaftar di Bursa Efek Indonesia pada tahun 2014-2018, dimana teknik pengambilan sampel pada penelitian ini dilakukan dengan menggunakan teknik purposive sampling, yang berarti unit sampel yang dihubungi disesuaikan dengan kriteria-kriteria tertentu (Wati, 2017) atau menurut Riduwan (2010) purposive sampling adalah teknik sampling yang digunakan peneliti jika peneliti mempunyai pertimbangan-petimbangan tertentu di dalam pengambilan sampelnya atau penentuan sampel untuk tujuan tertentu. 
Adapun kriteria sampel yang dikategorikan dalam penelitian ini antara lain:

1. Terdaftar sebagai perusahaan perkebunan di Bursa Efek Indonesia selama tahun 20142018.

2. Perusahaan yang konsisten mempublikasikan laporan keuangan yang telah diaudit selama tahun 2014-2018.

3. Perusahaan yang konsisten mempublikasikan laporan audit selama tahun 2014-2018

Tabel 3.

Hasil Penemuan Sampel

\begin{tabular}{|c|c|c|}
\hline No & Keterangan & Jumlah \\
\hline 1 & $\begin{array}{l}\text { Perusahaan perkebunan yang terdaftar di Bursa Efek Indonesia } \\
\text { selama tahun } 2014 \text { - } 2018\end{array}$ & 18 \\
\hline 2 & $\begin{array}{l}\text { Perusahaan yang tidak konsisten menyampaikan laporan } \\
\text { keuangan dan laporan audit selama tahun } 2014-2018\end{array}$ & (4) \\
\hline 3 & $\begin{array}{l}\text { Perusahaan perkebunan yang tidak terdaftar di Bursa Efek } \\
\text { Indonesia selama tahun } 2014 \text { - } 2018 \text { yang memiliki data yang } \\
\text { di perlukan untuk penelitian }\end{array}$ & (3) \\
\hline & $\begin{array}{l}\text { Jumlah sampel } \\
\text { Jumlah data observasi }\end{array}$ & $\begin{array}{c}11 \\
(5 \text { tahun } x \text { 11) }\end{array}$ \\
\hline
\end{tabular}

Sumber : data diolah, 2019

Sumber datanya adalah laporan keuangan perusahaan yang terdaftar di Bursa Efek Indonesia (BEI) periode 2014-2018 dengan men-download melalui situs www.idx.co.id.

Persamaan yang digunakan untuk regresi linier berganda :

$\mathrm{AD}=\alpha+\beta 1 \mathrm{UKP}-\beta 2 \mathrm{NPM}-\beta 3 \mathrm{DER}+\varepsilon$

Dimana :

$\mathrm{AD}=$ Audit delay

$\alpha \quad=$ Nilai konstanta (alpha)

$\beta \quad=$ Koefisien regresi

$\mathrm{UKP}=$ Ukuran perusahaan

NPM $=$ Net Profit margin

$\mathrm{DER}=$ Debt to equity ratio

\section{Analisis data yang digunakan :}

1. Analisis Deskriptif

Untuk mendapatkan gambaran secara keseluruhan mengenai variable-variabel yang digunakan, maka terlebih dahulu dilakukan analisis pada statistic deskriptif (Susilawati, 2020). Analisis deskriptif adalah statistika yang mempelajari segi-segi yang penting dari data. Analisisnya meliputi gambaran atau mendiskripsikan hal-hal dari suatu data seperti mean, median, modus, range, varian, frekuensi, nilai maksimun dan minimum, serta standar deviasi (Ghozali : 2013).

2. Pengujian hipotesis

Data yang digunakan adalah data panel. Data panel adalah data yang memiliki karakteristik cross section dan time series secara bersamaan sehingga proses pengolahan data menggunakan eviews dengan melakukan uji kelayakan model terlebih dahulu (Chow Test, Uji Hausman, Uji Lagrange Multiplier). Kelebihan data panel adalah tidak diperlukannya melakukan uji asumsi klasik (Wati, 2017). 
Dasar pengujian yang digunakan adalah menggunakan nilai sign. 5\%. Dengan pengambilan keputusan (Wati, 2017) :

a. Bila $\mathrm{t}$ hitung lebih kecil dari $\mathrm{t}$ tabel ( $\mathrm{t}$ hitung $<\mathrm{t}$ tabel) berarti $\mathrm{H}_{0}$ diterima, maka secara parsial variabel independen tidak mempunyai pengaruh secara signifikan terhadap variabel dependen

b. Bila $\mathrm{t}$ hitung lebih besar dari $\mathrm{t}$ tabel ( $\mathrm{t}$ hitung $>\mathrm{t}$ tabel) berarti $\mathrm{H}_{0}$ ditolak, maka secara parsial variabel independen mempunyai pengaruh secara signifikan terhadap variabel dependen.

Pengambilan keputusan berdasarkan probabilitas adalah :

a. Jika probabilitas $>$ tingkat signifikan $(\mathrm{Sig}>0,05)$ maka $\mathrm{H}_{0}$ diterima

b. Jika probabilitas < tingkat signifikan (Sig < 0,05), maka $\mathrm{H}_{0}$ ditolak

\section{PEMBAHASAN}

Analisis deskriptif

Tabel 4.

Deskripsi Variabel Penelitian

\begin{tabular}{lcrrr}
\hline \hline & AD & UKP & \multicolumn{1}{c}{ NPM } & \multicolumn{1}{c}{ DER } \\
\hline \hline Mean & 70.85455 & 29.88929 & -0.066055 & 0.746909 \\
Median & 78.00000 & 29.87800 & 0.068000 & 1.240000 \\
Maximum & 135.0000 & 31.17780 & 0.338000 & 11.27000 \\
Minimum & 37.00000 & 28.32420 & -2.840000 & -30.64000 \\
Std. Dev. & 20.36738 & 0.811545 & 0.459213 & 4.870736 \\
Skewness & 0.340823 & -0.047449 & -4.381942 & -5.009265 \\
Kurtosis & 3.224749 & 1.834196 & 25.76537 & 33.44691 \\
& & & & \\
Jarque-Bera & 1.180559 & 3.135237 & 1363.697 & 2354.425 \\
Probability & 0.554172 & 0.208541 & 0.000000 & 0.000000 \\
& & & & \\
Sum & 3897.000 & 1643.911 & -3.633000 & 41.08000
\end{tabular}

Sumber : Eviews, data diolah, 2019

Berdasarkan tabel diatas diketahui bahwa dari 55 data observasi terdapat nilai tertinggi pada nilai maximum audit delay sebesar 138,00, sedangkan untuk yang terendah terdapat pada nilai minimum debt to equity ratio sebesar -30,64. Pada table tersebut terdapat juga nilai yang negative yaitu; sebesar $-0,05$ terdapat pada nilai skewness ukuran perusahaan, pada nilai net profit margin sebesar $-0,06,-2,84$ dan $-4,38$. Terdapat juga pada nilai debt to equity ratio sebesar $-30,64$ dan $-5,00$

Nilai Ukuran Perusahaan mempunyai nilai mean (rata-rata) 29,89 dengan standar deviasi 0,81 . Untuk nilai maksimumnya sebesar 31,18 dan nilai minimumnya adalah 28,32 . Net Profit Margin (NPM) mempunyai mean (rata-rata) -0,066 dengan standar deviasi 0,46 Untuk nilai maksimumnya sebesar 0,34 dan nilai minimumnya adalah -2,84. Debt Equity Ratio (DER) mempunyai mean (rata-rata) 0,75 dengan standar deviasi 4,87 Untuk nilai maksimumnya sebesar 11,27 dan nilai minimumnya adalah -30,64.

Untuk variabel dependen Audit Delay mempunyai mean (rata-rata) 70,85 dengan standar deviasi 20,37. Untuk nilai maksimumnya sebesar 135,0 dan nilai minimumnya adalah 37,0 . 
Tabel 5.

Hasil Pengujian Model Penelitian

Hasil Regresi Random Effect Model

\begin{tabular}{crrrr}
\hline \hline Variable & Coefficient & Std. Error & t-Statistic & Prob. \\
\hline \hline C & 254.4961 & 130.6703 & 1.947620 & 0.0570 \\
UKP & -6.133374 & 4.368168 & -1.404107 & 0.1663 \\
NPM & -3.109293 & 3.467485 & -0.896700 & 0.3741 \\
DER & -0.702623 & 0.276689 & -2.539401 & 0.0142 \\
\hline \hline
\end{tabular}

Sumber : Eviews, data diolah, 2019

Audit Delay $=254,4961-6,133374$ UKP - 3,109293NPM - 0,702623DER

Interpretasinya adalah :

Konstanta dengan nilai 254,4961 menunjukkan bahwa jika Ukuran Perusahaan, Net Profit Margin (NPM) dan Debt to Equity Ratio (DER) sama dengan nol (0) maka Audit Delay bernilai 0,5255. Nilai koefisien Ukuran Perusahaan sebesar -6,13 artinya menunjukkan bahwa jika Ukuran Perusahaan naik satu satuan dengan asumsi variabel lain tetap maka akan Menurunkan Audit Delay sebesar 6,13 hari. Nilai koefisien Net Profit Margin (NPM) sebesar 3,11 artinya menunjukkan bahwa jika Net Profit Margin (NPM) naik satu satuan, dengan asumsi variabel lain tetap maka akan menurunkan Audit Delay sebesar 3,11 hari. Nilai koefisien Debt Equity Ratio (DER) sebesar -0,70 artinya menunjukkan bahwa jika Debt Equity Ratio (DER) naik satu satuan, dengan asumsi variabel lain tetap maka akan menurunkan Audit Delay sebesar 0,70 hari.

Hasil uji t, adalah sebagai berikut:

Ukuran Perusahaan terhadap Audit Delay memiliki hasil t hitung sebesar -1,404 dengan tingkat signifikansi 0,166. Hal ini menunjukkan bahwa thitung lebih kecil daripada t tabel yaitu dengan nilai $-1,404<2,007584$, dengan nilai signifikan 0,166 $>0,05$. Sehingga hipotesis pertama (H1) ditolak, dapat disimpulkan bahwa Ukuran Perusahaan tidak berpengaruh signifikan terhadap Audit Delay. Hasil ini selaras dengan penelitian yang telah dilakukan oleh Karina Harjanto (2017), Khoufi (2018), Sari et al. (2014), Kowanda et al. (2016), dan Arisudhana (2012). Dari hasil tersebut di atas, menjelaskan bahwa besar/kecilnya ukuran perusahaan, yang dinilai dari seberapa besar nilai harta yang dimiliki perusahaan, tidak mempengaruhi lamanya audit delay. Hal tersebut disebabkan oleh penilaian ukuran perusahaan menggunakan total assets dimana dinilai lebih stabil dibandingkan jika menggunakan market value atau tingkat penjualan, ukuran perusahaan yang dinilai dari total assets tidak mempengaruhi lamanya audit delay. Hasil penelitian ini bertolak belakang dengan yang dikemukakan oleh Puspitasi dan Latrini (2014) bahwa ukuran perusahaan memiliki pengaruh signifikan terhadap audit delay dikarenakan semakin besar perusahaan maka perusahaan itu memiliki sistem pengendalian internal yang baik sehingga dapat mengurangi tingkat kesalahan laporan keuangan dan pengauditan atas laporan keuangan dapat dilakukan dengan lebih cepat. Selain itu, perusahaan besar diawasi oleh investor dan pengawas permodalan pemerintah.

Net Profit Margin (NPM) terhadap Audit Delay memiliki hasil t hitung sebesar -0,0896 dengan tingkat signifikansi 0,3741. Hal ini menunjukkan bahwa t hitung lebih kecil daripada $t$ tabel yaitu dengan nilai $-0,896<2,007584$, dengan nilai signifikan 0,3741 $>0,05$. Sehingga hipotesis kedua (H2) ditolak, dapat disimpulkan bahwa Net Profit Margin (NPM) tidak berpengaruh signifikan terhadap Audit Delay. Hasil ini selaras dengan penelitian yang dilakukan oleh Sinurat dan Sitanggang (2015), Kowanda et al. (2016). Hal ini menunjukkan bahwa tinggi rendahnya profitabilitas (NPM) tidak mempengaruhi terhadap adanya audit delay. 
Debt to Equity Ratio (DER) terhadap Audit Delay memiliki hasil t hitung sebesar -0,7026 dengan tingkat signifikansi 0,0142. Hal ini menunjukkan bahwa t hitung lebih besar daripada $t$ tabel yaitu dengan nilai $-2,539>2,007584$ dengan nilai signifikan $0,0000<0,05$. Sehingga hipotesis ketiga (H3) yang menyatakan pengaruhnya positif ditolak , dapat disimpulkan bahwa Debt to Equity Ratio (DER) berpengaruh negatif dan signifikan terhadap Audit Delay. Hasil penelitian ini selaras dengan penelitian yang dilakukan oleh Sari et al. (2014) menunjukkan hasil penelitiannya bahwa Debt to Equity Ratio berpengaruh negatif signifikan terhadap Audit Delay, namun bertentangan dengan hasil penelitian Eksandy (2017), Khoufi (2018) dimana Debt to Equity Ratio tidak berpengaruh signifikan terhadap Audit Delay. Hal tersebut terjadi karena perusahaan yang memiliki hutang yang tinggi akan memiliki insentif untuk menyelesaikan pekerjaan audit sehingga cenderung tidak melakukan Audit Delay.

\section{PENUTUP}

\section{Simpulan}

Berdasarkan hasil penelitian di atas maka dapat disimpulkan bahwa ukuran perusahaan tidak berpengaruh terhadap audit delay. Dapat diartikan bahwa besar kecilnya perusahaan tidak menentukan bahwa perusahaan tersebut akan melakukan penundaan atau keterlambatan dalam penyampaian laporan keuangan. Sampel yang digunakan juga berasal dari perusahaan yang terdaftar di BEI sehingga memungkinkan perusahaan-perusahaan melaporkan laporan keuanganya lebih cepat dari perusahaan yang lain untuk dapat menarik perhatian investor, serta agar tidak terkena sanksi dari pengawas permodalan juga pemerintah.

Net profit margin tidak berpengaruh terhadap audit delay, pada umumnya beberapa perusahaan mengalami kenaikan profit yang tidak terlalu besar atau bahkan merugi, hal ini memungkinkan tuntutan dari yang berkepentingan tidak terlalu tinggi sehingga tidak berpengaruh terhadap faktor audit delay.

Debt to equty ratio berpengaruh negatif signifikan terhadap audit delay, peningkatan utang akan memberikan tekanan pada perusahaan untuk mempublikasikan laporan keuangannya dan perusahaan yang memiliki utang besar akan cenderung lebih cepat dalam penyampain laporan keuangannya agar jaminannya dapat diberikan kepada para pemilik modal.

\section{Saran}

Penelitian ini yang dilakukan tidak terlepas dari adanya keterbatasan dan kekurangan. Dalam penelitian ini keterbatasannya adalah peneliti hanya menggunakan sedikit sampel, sehingga memungkinkan lemahnya hasil penelitian. Penelitian selanjutnya hendaknya menambah/memperluas jumlah sampel dan juga melibatkan sektor industri yang lain agar mencerminkan reaksi dari pasar modal secara keseluruhan. Selain itu sebaiknya menambahkan variabel lain seperti Ukuran Kantor Akuntan Publik, Audit Tenure, Likuiditas, Komite Audit, jenis industri yang berbeda, dan lainnya. Sehingga diperoleh temuan yang lebih baik dalam menjelaskan tentang faktor-faktor yang mempengaruhi Audit Delay

\section{REFERENSI}

Aditya, Alifian Nur dan Indah. A. (2014). Faktor-faktor Yang Berpengaruh Terhadap Audit Delay. Accounting Analysis Journal, AAJ 3 (3) 2014. Hal 334-342.

Annisa, D. (2018). Pengaruh Ukuran Perusahaan, Jenis Opini Auditor, Ukuran Dan Audit Tenure terhadap Audit Delay. Jurnal Akuntansi Berkelanjutan Indonesia, Vol.1, No.1, Januari 2018. Hal. 108-121.

Dewayani, Mega A., Moh. A. A \& Veni. S. D. (2017). Analisis Faktor-Faktor Yang Memengaruhi Ketepatan Waktu Pelaporan Keuangan (Studi Empiris pada Perusahaan Manufaktur yang Terdaftar di Bursa Efek Indonesia Periode 2011-2016). ISSN 24079189. URECOL, Juni 2017, Hal. 441-458. 
Eksandy, A. (2017). Pengaruh Ukuran Perusahaan, Solvabilitas, Profitabilitas dan Komite Audit terhadap Audit Delay (Pada Perusahaan Property dan Realestate yang Terdaftar di Bursa efek Indonesia Pada Tahun 2012-2015. E-ISSN 2549-791X, Competitive Jurnal Akuntansi dan Keuangan, Vol.1, No.2, 2 Juli - Desember 2017.

Ghozali, Imam. 2013. Aplikasi Analisis Multivariate dengan Program IBM SPSS 21 Update PLS Regresi. Semarang: Badan Penerbit Universitas Diponegoro.

Gilling M. D (1977) “Timeliness in Corporate Reporting: Some Further Comment”, Accounting and Business Research, Winter, pp. 35-50.

Harahap, Sofyan Syafari. 2011. Analisa Kritis Atas Laporan Keuangan. Cetakan 11. Jakarta: PT. Rajagrafindo Persada Persada. 2010. Analisis Kritis atas laporan Keuangan . Jakarta: Raja Grafindo

Harjanto, K. (2017). Pengaruh Ukuran Perusahaan, Profitabilitas, Solvabilitas dan Ukuran Kantor Akuntan Publik terhadap Audit delay. Ultima Accounting, Vol. 9 No.2, 2 Desember 2017. Hal. 33-49.

Indra, Novelia Sagita, \& Dicky. A. (2012). Faktor-Faktor Yang Mempengaruhi Audit Delay Pada Perusahaan Go Public Di Indonesia (Studi Empiris pada Perusahaan Property dan Real Estate di Bursa Efek Indonesia periode 2007-2010). Jurnal Akuntansi dan Keuangan, Volume 1, No.2, Hal. 165-185.

Kowanda, Dionysia., Rowland. B.F. P. \& Fikriansyah (2016). Antesedan Audit Delay Pada Emiten LQ45 Di bursa Efek Indonesia. Jurnal Riset Akuntansi dan Keuangan, volume 12, No.12.

Lestari, Kadek A. N. M \& Putu. W. S. (2017). Analisis Pengaruh Ukuran Perusahaan, Profitabilitas, Solvabilitas, Kualitas Auditor dan Audit Tenure Terhadap Audit Delay Pada Perusahaan Manufaktur di Bursa efek Indonesia Periode 2012-2015. E-ISSN 23018291, Jurnal ilmiah Manajemen dan Akuntansi, Vo. 23, No.1 Juni 2017. Hal. 1-11.

Megayanti, Putu \& I Ketut. B. (2016). Pengaruh Pergantian Auditor, Ukuran Perusahaan, Laba Rugi dan Jenis Perusahaan Pada Auditor Lag. ISSN : 2302-8556, E- Jurnal Akuntansi Universitas Udayana. 14.2 (2016). Hal. 1481-1509

Munawaroh. Mamlu A. \& Ramdany. 2019. Peran CSR, Ukuran Perusahaan. Karakteristik Eksekutif dan Koneksi Politik Terhadap Potensi Tax Avoidance. Jurnal AKUNTANSI, Volume 8, Nomor 2, November 2019. Halaman 109-121.

Ningsih, I Gusti. A. P \& Ni Luh. S.W. (2015). Pengaruh Ukuran Perusahan, Laba Operasi, Solvabilitas dan Komite Audit Pada Audit Delay. ISSN : 2302-8556, E-Journal Akuntansi Universitas Udayana, Hal. 481-495.

Ketut Dian Puspitasari, M. Y. (2014). Pengaruh Ukuran Perusahaan, Anak Perusahaan, Leverage dan Ukuran KAP terhadap Audit Delay. E-Jurnal Akuntansi Universitas Udayana, hal. 283-299.

Khoufi, N. and Walid K. (2018). An empirical examination of the determinants of audit report delay in France. Managerial Auditing Journal, Emerald Publishing Limited. DOI 10.1108/MAJ-02-2017-1518, Vol. 33 No. 8/9, 2018, P. 700-714

Prabasari, I Gusti. A. A. R, \& Ni Ketut .L.A.M. (2017). Pengaruh Profitabilitas, Ukuran Perusahaan, dan Komite Audit Pada Audit Delay Yang Dimoderasi Ole Reputasi KAP. E-Journal Akuntansi Universitas Udayana, Vol.20.2, Agustus 2017. Hal. 1704-1733.

Puspitasari, K. D \& Made Y. L. (2014). Pengaruh Ukuran Perusahaan, Anak Perusahaan, Leverage dan Ukuran KAP terhadap Audit Delay . ISSN: 2302-8556, E-Jurnal Akuntansi Universitas Udayana, 8.2 (2014): 283-299.

Putra, Putu. G. O. S \& I Made. P. D. P. (2016). Ukuran Perusahaan sebagai Pemoderasi Pengaruh Opini Auditor, Profitabilitas dan Debt to Equity ratio Terhadap Audit Delay. ISSN : 2302-8559, E-Jurnal Akuntansi Universitas Udayana, 14.3, Hal. 2278-2306.

Riduwan. 2010. Metode dan Teknik Menyusun Tesis. Bandung : Alfabeta 
Saemargani, F. I \& Indah. M. (2015). Pengaruh Ukuran perusahaan, Umur Perusahaan, Profitabilitas, Solvabilitas, Ukuran KAP dan opini Auditor Terhadap Audit delay. Jurnal Nominal, Volume IV Nomor 2, 20015. Hal 1-15.

Sari, I. P., R. Adri. S \& Elfi, I. (2014). Pengaruh ukuran perusahaan, solvabilitas dan reputasi kap terhadap audit delay pada perusahaan property \& real estate di Bursa Efek Indonesia periode 2009-2012. JOM FEKON , Vol. 1 Nomor. 2 Oktober 2014.

Supriyati, Rosmawati E. I. 2012. Faktor-faktor Yang Mempengaruhi Audit Report Lag Perusahaan Manufaktur Di Indonesia dan Malaysia. Jurnal Riset Akuntansi dan Keuangan. Volume 2, No. 2, Juli 2012. Hal. 185-202.

Susilawati, S. (2020). Determian Harga Saham Perusahaan yang Terdaftar di LQ45. Jurnal Akrab Juara. Volume 5, Nomor. 1 Edisi Februari 2020 (38-39).

Wahyuningisih, S. (2016). Pengaruh Ukuran Perusahaan, Umur Perusahaan, Profitabilitas, dan Solvabilitas terhadap Audit Delay (Studi Pada Perusahaan Perbankan yang terdaftar di BEI). E-Journal Ekonomi dan Bisnis, 1-12.

Wati, Lela Nurlaela. 2017. Metodologi Penelitian Bisnis Terapan Aplikasi SPSS, Eviews, Smart PLS, dan AMOS. Bandung : CV. Mujahid Press

\section{Website :}

www. idx.co.id 